\title{
MODEL DISTRIBUSI GULA KELAPA YANG OPTIMAL
}

\author{
Nikmatul Khoiryah (Unisam) \\ Masyhuri (Unisma) \\ 'Amul Jadidah (UIN)
}

\begin{abstract}
Distribution channel has a great influence in marketing a certain product. It has become a serious problem faced by the entrepreneur of brown sugar in Nglegok district, Blitar. Not a few of them have a financial loss due to the fact that the product is not distributed efficiently. This research is aimed at knowing about the distribution channel of brown sugar optimally that which is suitable to the selling target. In addition, it is also aimed at detecting the network of brown sugar market.This research is a quantitative descriptive research using a transport method which applies both an analysis of NWCR (North West Corner Method), MODI (Modified Distribution Method) and a network analysis. From the analysis of NWCR Initial Solution for the distribution channel it is known that an is optimal distribution channel has the amount of Rp. 6.938.166. The distribution channel, which is appropriate to the selling target is indicated by recommendation of allocation in distributing brown sugar for distributor II as much as $10.500 \mathrm{~kg} / \mathrm{week}$ to Pare, $13.300 \mathrm{~kg} /$ week to Jombang, and $700 \mathrm{~kg} /$ week to Tulungagung, to the distributor III as much as $2800 \mathrm{~kg} /$ week to Tulungagung and $1200 \mathrm{~kg} /$ week to Tuban. The allocation in distributing brown sugar for the distributor IV is as much as $1400 \mathrm{~kg} /$ week to Babat, 4600, $70 \mathrm{~kg} /$ week to Surabaya, 2300, $30 \mathrm{~kg} /$ week to Talun and $2000 \mathrm{~kg} /$ week to Batu. Therefore, the optimal solution for the channel distribution by MODI analysis is Rp. 773.314. Absolutely, the amount is by recommendation of allocation in distributing brown sugar to the channel distribution that is proper to the target market as much as $700 \mathrm{~kg} / \mathrm{week}$ to Pare and $800 \mathrm{~kg} /$ week to Jombang for the distributor I, for the distributor II is $1000 \mathrm{~kg} /$ week to Wlingi, $500 \mathrm{~kg} /$ week to Kesamben, $5800 \mathrm{~kg} /$ week to Pare, $3500 \mathrm{~kg} /$ week to Tulungagung, $1200 \mathrm{~kg} /$ week to Tuban, $1400 \mathrm{~kg} /$ week to Babat, $4600,70 \mathrm{~kg} /$ week to Surabaya, $2300,30 \mathrm{~kg} /$ week to Talun and $2000 \mathrm{~kg} /$ week to Batu, for the distributor III, is $4000 \mathrm{~kg} / \mathrm{week}$ to Pare, and for the distributor IV is $12500 \mathrm{~kg} / \mathrm{week}$ to Jombang. The network marketing, which supports the distribution of sugar brown, is indicated by varying route of shortest shipping to the distribution channel aimed. From the analysis, Pare becomes the alternative place for the shipping of brown sugar.
\end{abstract}




\section{Pendahuluan}

Pendistribusian produk sering kali menjadi masalah serius yang dihadapai oleh banyak perusahaan. Tidak sedikit yang mengalami kerugian akibat hilangnya peluang penjualan, bahkan surutnya brand image sebuah produk akibat dari produk tersebut tidak didistribusikan secara baik dan optimal (Rayon, 2005:309)

Banyaknya persaingan pada lingkungan industri gula kelapa, Kompetisi dipasar sangat ketat dan pola perilaku konsumen yang sangat berubah-ubah seperti banyaknya konsumen yang menginginkan dapat memperoleh tingkat harga yang rendah, menuntut marketer untuk mengiplementasikan strategi pemasarannya agar produk bisa sampai kepada pasar sasaran. Untuk mengimplementasikan strateginya, memerlukan biaya pemasaran yang cukup besar. Untuk mereduksi biaya pemasaran tersebut, para marketer industri gula kelap bisa meminimalkan biaya pemasarannya dengan cara mengoptimalkan saluran distribusi, memilih saluran distibusi yang sesuai dengan pasar sasaran dan minimasi jaringan pemasaran atau efisiensi jaringan pemasaran

\section{Tujuan Penelitian}

1. Untuk mengetahui saluran distribusi Gula kelapa yang optimal.

2. Untuk mengetahui saluran distribusi Gula kelapa yang sesuai dengan target pasar sasaran.

3. Untuk mendeteksi jaringan pemasaran Gula kelapa

\section{Pemasaran dan Manajemen Pemasaran}

\section{Kajian Teoritis}

Menurut Kotler (2001:100-101) pemasaran adalah proses sosial dan manajerial dimana seseorang atau kelompok memperoleh apa yang mereka butuhkan dan inginkan melalui penciptaan dan pertukaran produk dan nilai. manajemen pemasaran adalah kegiatan penganalisaan, pelaksanaan, pengendalian atas program yang telah ditetapkan untuk mencapai tujuan dan memperoleh keuntungan.

\section{Distribusi dan Saluran Distribusi}

Menurut Tjiptono (1997:185) pendistribusian dapat diartikan sebagai kegiatan pemasaran yang berusaha memperlancar dan mempermudah penyampaian barang dan jasa dari produsen kepada konsumen, sehingga penggunaannya sesuai dengan yang diperlukan (jenis, jumlah, harga, tempat, dan saat dibutuhkan). Dengan kata lain, proses pendistribusian merupakan aktivitas pemasaran yang mampu:

1. Menciptakan nilai tambah produk melalui fungsi-fungsi pemasaran yang dapat merealisasikn kegunaan/utilitas bentuk, tempat, waktu, dan 
kepemilikan.

2. Memperlancar arus saluran pemasaran (marketing channel flow) secara fisik dan non-fisik. Yang dimaksud dengan arus pemasaran adalah aliran kegiatan yang terjadi diantara lembaga-lembaga pemasaran yang terlibat dalam proses pemasaran. Arus pemasaran tersebut meliputi arus barang fisik, arus kepemilikan, arus informasi, arus promosi, arus negosiasi, arus pembayaran, arus pendanaan, arus penanggunan resiko, dan arus pemesanan.

saluran distribusi adalah lembaga-lembaga distributor atau lembagalembaga penyalur yang mempunyai kegiatan untuk menyalurkan atau menyampaikan barang/jasa dari produsen hingga sampai ke konsumen akhir atau rute/rangkaian perantara baik yang dikelola pemasar maupun yang independen dalam menyampaikan barang dari produsen ke konsumen

\section{Metode Transportasi}

Metode trasnportasi adalah metode yang paling efisien. Penggunaan metode transportasi ini dipelopori oleh F.L Hitcock (1941), T.C Koopmans (1949) dan GB. Dantzing (1951). Beberapa permasalahan yang dapat diselesaikan dengan metode transportasi adalah mengalokasikan barang/jasa dari suatu tempat (sumber/supplay) ke tempat lainnya (demand/destination) secara optimal dengan mempertimbangakan biaya minimal, pengalokasian periklanan yang efektif, pembelanjaan modal dan alokasi dana untuk invesatasi, analisis pemilihan lokasi usaha yang tepat, keseimbangan lini perakitan, penjadwalan produksi, dan lain-lain (Zulfikarijah, 2004:92).

Pemodelan transportasi (transportation modeling ) mencari cara yang termurah untuk mengirimkan barang dari beberapa sumber ke beberapa tujuan. Titik asal (atau sumber) dapat berupa pabrik, gudang, agen penyewaan mobil seperti avis, atau titik lain dari mana barang-barang dikirim. Tujuan adalah titiktitik yang menerima barang. (Heizer dan Render, 2004:391)

Hasil akhir dari metode transportasi adalah suatu solusi optimal dari fungsi tujuan dengan batas kendala yang ada. Terdapat beberapa metode yang dapat digunakan untuk menyelesaikan kasus transportasi ini, yaitu metode simplek, north west corner method, vogel approximation metod, least cost method, integer programming, dynamic programming, dan sebagainya .(Agustin dan Rahmadi, 2004:101-102)

\section{Jaringan}

Jaringan adalah suatu sistem garis-garis atau saluran-saluran yang menghubungkan titik-titik yang berlainan (Mulyono, 2004:111)

Jaringan merupakan gambaran dari peristiwa dan aktivitas. Dalam pendistribusian suatu barang, perusahaan dapat menggunakan analisis jaringan (Network Analisys) yang memungkinkan perusahaan untuk mengetahui jalur atau kegiatan mana saja yang merupakan fokus utama atau kritis, sehingga dapat 
mengukur efisiensi pelaksanaan distribusi dengan membandingkan antara perpendekkan waktu dengan biaya yang dikeluarkan (www.elibrary.mb.ipb.ac.id)

Secara umum dapat dikatakan bahwa analisis jaringan digunakan untuk membantu menyelesaikan masalah-masalah yang muncul dari serangkaian pekerjaan. Masalah masalah yang dimaksud antara lain adalah :a)Waktu penyelesaian dari serangkaian pekerjaan tersebut. b)Biaya yang harus dikeluarkan untuk melaksanakan serangkaian pekerjaan tersebut. c)Waktu menganggur yang terjadi di setiap pekerjaan. d)Mendesain system transportasi (seperti penentuan rute terdekat atau penentuan arus maksimal pada suatu jalur). e)Mendesain informasi. f)Membuat skedul suatu proyek, dll.

Analisis jaringan ini pertama kali dikembangkan oleh perusahaan jasa konsultan manajemen Boaz, Allen dan Hamilton yang dibuat untuk keperluan perusahaan pesawat terbang Lockhead. Metode yang biasanya digunakan sering disebut dengan PERT yang merupakan singkatan dari Program Evaluation and Review Tachnique. Tanpa bermaksud meniru, ada juga metode CPM (Critical Path Method) yang dapat digunakan untuk menyelesaikan masalah jaringan ini. Perbedaan utamanya adalah, lebih menekankan pada efisiensi biaya pelaksana serangkaian pekerjaan, dengan mempercepat salah satu atau beberapa kegiatan dalam rangkaian pekerjaan tersebut. (www.elibrary.mb.ipb.ac.id).

\section{Kajian Teori Dalam Perspektif Islam}

Distribusi merupakan komponen penting dalam pelaksanaan suatu bisnis. Diakui bahwa distribusi adalah merupakan bagian terpenting dalam ekonomi. Distribusi dalam ekonomi kapitalis terfokus pada pacsa produksi yaitu sebagai konsekuensi dari pada proses produksi bagi setiap proyek, baik dalam bentuk uang maupun nilai, lalu hasil tersebut didistribusikan pada komponen-komponen produksi yang terlibat didalamnya. Komponen-komponen tersebut meliputi upah, bunga, ongkos, dan keuntungan (Qardhawi, 2001:374).

Sedangkan distribusi dalam ekonomi islam didasarkan pada 2 nilai manusiawi yang mendasar dan penting yaitu kebebasan dan keadilan.

Pada umumnya, kemacetan dalam mendistribusikan barang-barang dan jasa-jasa akan banyak menimbulkan kesulitaan baik dipihak konsumen maupun produsen. Kesulitan yang akan terjadi di pihak produsen meliputi terganggunya penerimaan penjualan sehingga target penjualan yang telah di tentukan tidak dapat terpenuhi. Hal ini akan menyebabkan arus pendapatan yang dibutuhkan oleh perusahaan untuk melangsungkan kontinuitasnya tidak dapat diharapkan. Sedangkan kesulitan yang akan timbul di pihak konsumen akan menyebabkan tendensi harga yang meningkat. Tendensi harga yang meningkat terjadi akibat berkurangnya barang yang ditawarkan di pasar. Sehingga dalam pendistribusian harus mencipatan unsur-unsur yang telah diterangkan pada surat diatas tersebut. 


\section{Metode Penelitian}

\section{Jenis dan Sumber Data}

Penelitian ini merupakan penelitian deskriptif kuantitatif dengan menggunakan metode Transportasi dengan analisis NWCR (North West Corner Method), MODI (Modified Distribution Methode) dan analisis jaringan.

Penelitian dilakukan pada para pengusaha (pengepul) gula kelapa yang tersebar di Kecamatan Nglegok Kabupaten Blitar.

\section{Metode Analisis Data}

Untuk Menjawab tujuan pertama dan kedua metode analisi data yang digunakan dalam penelitian ini adalah dengan menggunkan metode transportasi.

\section{Prosedur Penyelesaian Metode Transportasi}

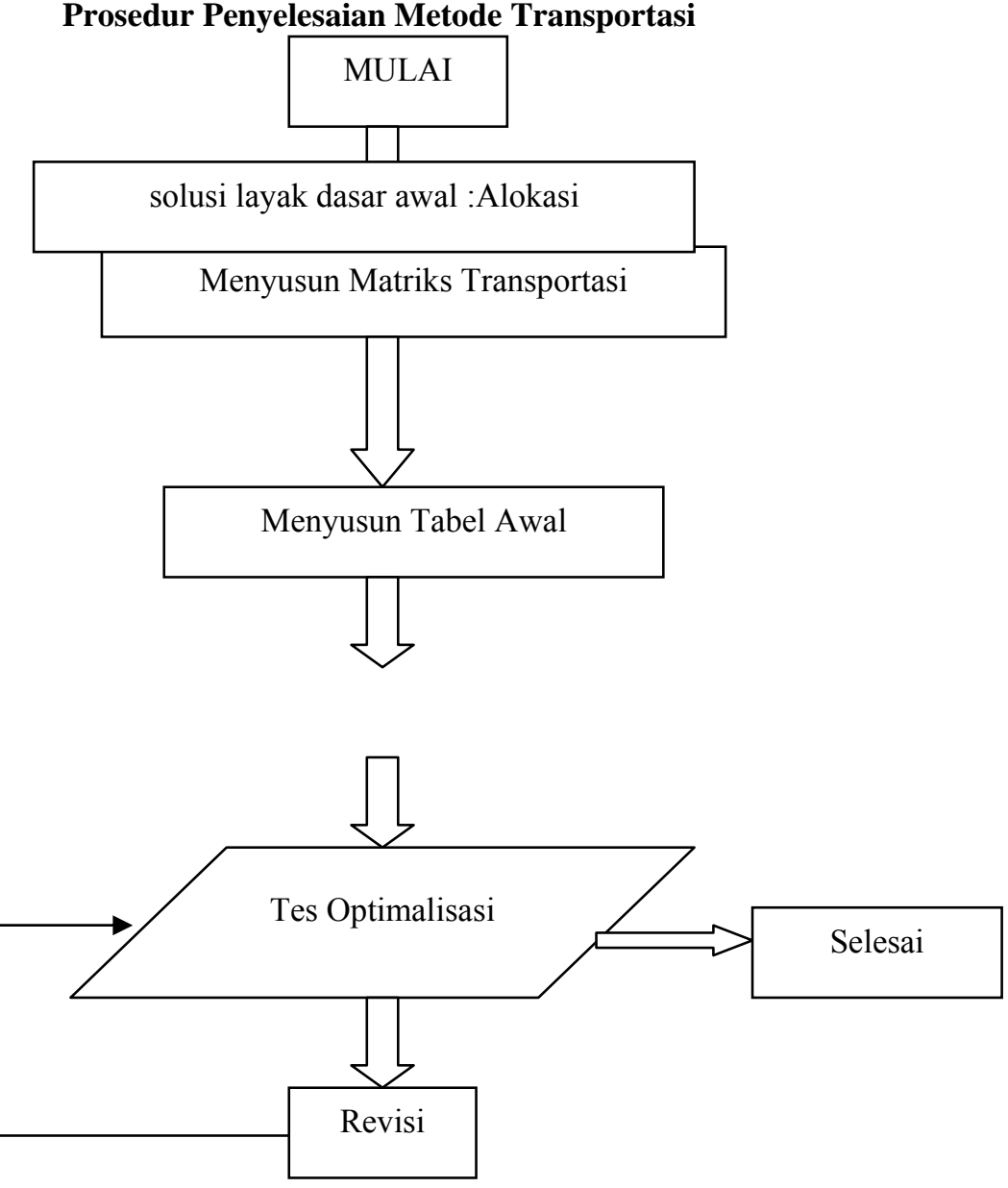


(Sumber: Agustin dan Yus Endra Rahmadi, 2004:102)

Adapun prosedur penyelesaian metode transportasi menurt Masyhuri, dkk (2008:40-43) adalah sebagai berikut:

\section{Langkah 1}

Langkah pertama didalam metode transportasi adalah menyusun matriks transportasi. Langkah ini merupakan kunci keberhasilan kita dalam langkah berikutnya. Matrik transportasi menunjukkan sumber dari mana barang berasal dan tujuan kemana barang dikirim.

Matrik Transportasi

\begin{tabular}{|c|c|c|c|c|c|c|c|c|}
\hline \multirow{2}{*}{\multicolumn{2}{|c|}{$\mathrm{Ke}$}} & \multicolumn{6}{|c|}{ Tujuan } & \multirow{2}{*}{ Supply } \\
\hline & & 1 & 2 & ... & $J$ & ... & $n$ & \\
\hline \multirow{3}{*}{-} & 1 & $\begin{array}{lll}\mathrm{X}_{11} & \mathrm{C}_{11} \\
\end{array}$ & $\mathrm{C}_{12}$ & $\ldots$ & $\mathrm{C}_{11}$ & $\ldots$ & $\mathrm{X}_{1 \mathrm{n}} \mathrm{C}_{1 \mathrm{n}}$ & $\mathrm{S}_{1}$ \\
\hline & 2 & $\mathrm{X}_{21} \mathrm{C}$ & $\mathrm{X}_{2 \sqrt{\mathrm{C}}}$ & ... & $\mathrm{X}_{21} \mathrm{C}$ & ... & $\mathrm{X}_{2 \mathrm{n}} \mathrm{C}$ & $\mathrm{S}_{2}$ \\
\hline & . & & $C_{22}$ & & 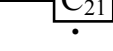 & & $-2 n$ & - \\
\hline 0 & - & - & - & & - & & - & - \\
\hline \multirow[t]{2}{*}{ م } & . & - & . & & - & & . & . \\
\hline & $\mathrm{i}$ & & & $\ldots$ & & $\ldots$ & & $\mathrm{S}_{1}$ \\
\hline \multirow{2}{*}{$\begin{array}{l}\Xi \\
=\end{array}$} & . & $\mathrm{C}_{i 1}$ & $\mathrm{C}_{i 2}$ & & $\mathrm{C}_{i j}$ & & $\mathrm{C}_{\text {in }}$ & - \\
\hline & . & - & - & & - & & $\cdot$ & - \\
\hline \multirow[t]{2}{*}{ U } & . & . & • & & . & & . & . \\
\hline & $m$ & $\mathrm{X}_{\mathrm{m} 1}$ & $\mathrm{X}_{\mathrm{m} 2}$ & ... & $\mathrm{X}_{\mathrm{m} 1}$ & $\ldots$ & $\mathrm{X}_{\mathrm{mn}}$ & $\mathrm{S}_{\mathrm{n}}$ \\
\hline \multicolumn{2}{|c|}{ Demand } & $\mathrm{BC}$ & $\mathrm{D}_{2}$ & $\ldots$ & $\sqrt{\mathrm{C}_{m 1}}$ & $\ldots$ & $\mathrm{D} / \mathrm{C}_{m}$ & $\sum \mathrm{S}_{\mathrm{i}}=\sum \mathrm{D}_{\mathrm{j}}$ \\
\hline
\end{tabular}

\section{Langkah 2}

Langkah berikutnya menyusun tabel awal. Pada tabel awal diisikan informasi biaya transportasi, dari suatu sumber ke suatu tujuan tertentu, besar kapasitas sumber, dan besar permintaan. Pada langkah ini, harus dipastikan bahwa besar kapasitas (penawaran) harus sama (seimbang) dengan besar permintaan. Apabila terdapat ketidaksamaan maka harus dibuat sel dummy yang berisi besarnya ketidakseimbangan antara penawaran dan permintaan. Sel dummy dapat berupa sel baris ataupun sel kolom.

Langkah ketiga adalah mencari solusi layak dasar awal dengan melakukan pengalokasian berdasarkan beberapa metode. Pada bentuk umum masalah transportasi, terdapat $m$ kendala penawaran dan $n$ kendala permintaan, keseluruhannya terdapat $m+n$ kendala. Dalam suatu masalah transportasi, terdapat sebuah kendala yang berlebihan (redundant). Kondisi keseimbangan 
$\sum_{j=i}^{m} S i=\sum_{j=i}^{n} D j$, memberikan kenyataan bahwa jika $m+n-1$ kendala terpenuhi

kemudian $m+n$ persamaan juga akan terpenuhi. Hanya terdapat $m+n-1$ persamaan indpendent. Sehingga solusi awal hanya memiliki $m+n-1$ variabel basis. Adapun metode yang digunakan pada penelitian ini adalah metode NorthWest Corner, metode ini adalah metode yang paling sederhana dari beberapa metode lainnya untuk mencari solusi awal. Adapun langkah-langkahnya sebagai berikut:

1) Mulai pada pojok barat laut tabel dan alokasikan sebanyak mungkin pada X11 tanpa menyimpang dari kendala penawaran atau permintaan (artinya $\mathrm{X} 11$ ditetapkan dengan yang terkecil diantara nilai S1 dan D1)

2) Ini akan menghabiskan penawaran pada sumber 1 dan atau permintaan pada tujuan 1. Akibatnya, tak ada lagi barang yang dapat diaolokasikan ke kolom atau baris yang telah dihabiskan dan kemudian baris atau kolom itu dihilangkan kemudian dialokasikan sebanyak mungkin ke kotak di dekatnya pada baris atau kolom yang tak dihilangkan. Jika baik kolom maupun baris telah dihabiskan, pindahlah secara diagonal ke kotak berikutnya.

3) Lanjutkan dengan cara yang sama sampai semua penawaran telah Langkah 4 dihabiskan dan keperluan permintaan telah dipenuhi.

Jika telah dilakukan pengalokasian dengan model tersebut, langkah berikutnya adalah melihat apakah alokasi tersebut sudah optimal atau belum. Langkah ini dikenal dengan tes optimalisai. Dalam penelitian ini peneliti akan menggunakan metode MODI untuk menguji keoptimalan saluran distribusi. Metode MODI merupakan metode penyelaesaian kasus transportasi yang dikembangkan dari metode stepping stone. Kelebihan metode ini adalah penentuan sel kosong yang bisa menghemat biaya dapat dilakukan dengan prosedur yang lebih pasti dan tepat. Selain itu dengan metode ini dapat mencapai penyelesaian optimal dengan lebih cepat. Cara MODI cukup menelusuri satu saja jejak tertutup. Jejak ini digambarkan sesudah ditemukan sel dengan indeks yang mempunyai harga negatif terbesar. Maksudnya ialah untuk dapat menentukan sel yang akan masuk kedalam penyelesaian berikutnya seperti pada cara batu loncatan. Sama seperti batu loncatan, dalam cara MODI kita mulai dengan aturan pojok barat-laut (PBL) sesudah itu baru kita teruskan dengan MODI dengan melakukan langkahlangkah penyelesaian secara berurutan.

berikut:

Mekanisme dapat dilakukan langkah-langkah yang diperlukan, sebagai

Langkah 1 : Tes Kemerosotan (Degeneracy) 
Langkah kesatu dalam cara MODI ialah mengetes kemerosotan seperti juga dilakukan dalam batu loncatan. Alat tes menguji apakah $(m+n-1)$ sama dengan jumlah sel yang terisi.

\section{Langkah 2 : Menghitung harga indeks A dan T}

Langkah kedua ialah menghitung harga bilangan indeks, baik indeks baris (Ai) maupun indeks kolom (Tj) ini dilaksanakan dengan menitik beratkan pada sel yang sudah terisi, untuk itu berlaku rumus:

Dimana, $\mathrm{A} i$

$$
\mathrm{A} i+\mathrm{T} j=\mathrm{C} i j \mathrm{i}, \mathrm{j}=1,2,3
$$

$$
=\text { indeks baris }
$$

$\mathrm{Tj} \quad=$ Indeks Kolom

$\mathrm{Cij} \quad=$ harga dari tiap sel $(\mathrm{i}, \mathrm{j})$ yang terisi

Langkah 3 : Menghitung indeks yang ditingkatkan atau sel yang tidak terisi.

Langkah ini segera dilakukan begitu harga baris dan kolom sudah dihitung dengan menggunakan sel yang sudah terisi.

Langkah ini dapat ditempuh dengan rumus:

$$
\mathrm{I} i j=\mathrm{C} i j-\mathrm{A} i-\mathrm{T} j
$$

Dimana Ij adalah indeks yang kan ditingkatkan untuk setiap sel yang belum terisi. Langkah 4 : Jawaban Optimal

Untuk mendapat jawaban yang optimal, kita akan terus melakukan proses diatas berulang-ulang hingga indeks Iij semuanya sudah positif misanya, dengan menggunkan rumus $\mathrm{A} i+\mathrm{T} j=\mathrm{C} i j$ untuk Tabel MODI II, dapat diperoleh hargaharga Ai dan Tj.

Sekarang dapat dapat dicari indeks yang akan ditingkatkan dengan menggunakan rumus Iij $=\mathrm{C} i j-\mathrm{A} i-\mathrm{T} j$ kembali untuk Tabel MODI II. Misalkan sel $(1,2)$ kita misalkan lagi dengan $\mathrm{x}$ dan kemudian angkat 5 hingga $\mathrm{x}=5$. kemudian kita lakukan penyesuaikan terhadap sel-sel yang sudah terisi yang akhirnya kita dapat Tabel MODI III sebagai berikut.

Ternyata dapat dilihat bahwa semua indeks Iij untuk sel-sel yang kosong sudah positif. Ini berarti bahwa Tabel MODI III merupakan jawaban optimal. Jumlah ongkos minimum akhirnya dapat dihitung dengan menggunkan tabel ini.

Berdasarkan penjelasan diatas, sekarang kita dapat merumuskan cara MODI sebagai berikut:

Misalkan, $\mathrm{A} i=\mathrm{u} i$

$\mathrm{T} j=\mathrm{Vj}$; dimana $u i, v j$ merupakan variabel dari dua terhadap persoalan transportasi untuk distribusi gula kelapa.

Untuk sel-sel yang belum terisi, berlaku :

$$
\mathrm{Iij}=\mathrm{C}-(\mathrm{ui}-\mathrm{vi})
$$

Sel untuk mana terdapat :

Min. $\{$ Iij $\}=\min .\{$ Cij $-(u i-v j)\}$ adalah sel yang kan ditingkatkan ikut dalam penyelesaian selanjutnya.

Apabila sudah dicapai keadaan dimana: 


$$
\mathrm{u} i+\mathrm{v} j \leq \mathrm{C} i j \text { atau } \mathrm{Iij} \geq 0
$$

dimana $i=1,2 \ldots$ ., $m ; j=1,2$.. ,$n$

maka jawaba optimal sudah dicapai, sehingga :

$\operatorname{Max} . z=\sum_{i=1}^{m} a i u i+\sum_{j=1}^{n} b j v j$

Untuk menjawab tujuan ketiga, pada penelitian ini mengunakan analisi jaringan. Jaringan merupakan gambaran dari peristiwa dan aktivitas.

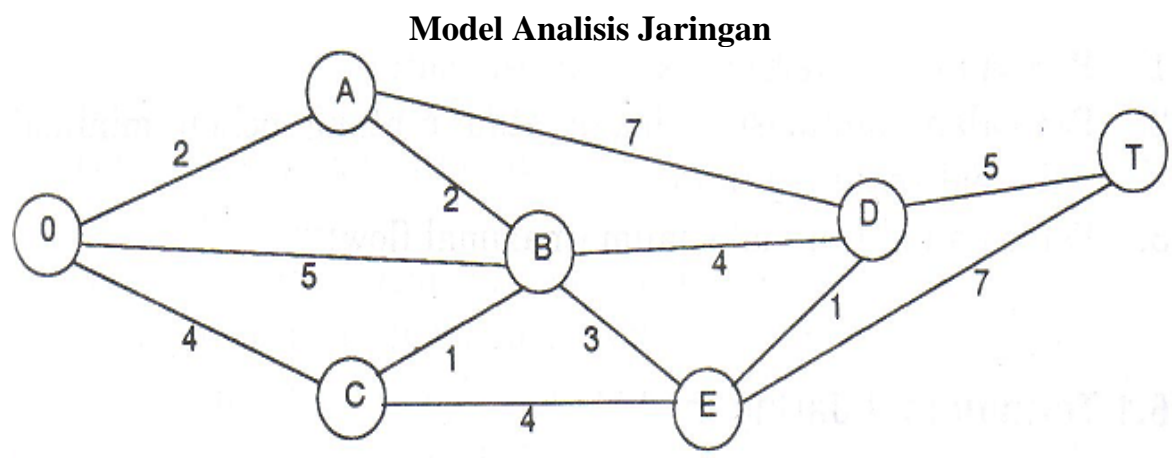

(Sumber: Dimyati dan Ahmad Dimyati, 1992:161)

\section{Langkah 0}

Node sumber diberi bobot $\mathrm{d}(\mathrm{s})=0$, sedangkan node lainnya diberi bobot $\mathrm{d}(\mathrm{s}, \mathrm{j})$, dimana $\mathrm{d}(\mathrm{s}, \mathrm{j})$ ini merupakan batas atas dari jarak terpendek dari node sumber kesuatu node j. Jika busur berlangsung $(\mathrm{s}, \mathrm{j})$ tidak ada, maka $\mathrm{d}(\mathrm{s}, \mathrm{j})=--$. Pilihlah $\mathrm{d}(\mathrm{s}, \mathrm{j})$ minimum dan beri tanda pada node $\mathrm{j}$ yang bersangkutan. Misalkan node $\mathrm{j}$ yang ditandai pada langkah 0 adalah node j1, maka j1 menjadi S1.

\section{Langkah 1}

Untuk setiap node $\mathrm{j}$ yang belum bertanda, carilah $\mathrm{d}(\mathrm{s} 1, \mathrm{j})=\min \{\mathrm{d}(\mathrm{s}, \mathrm{j} 1)+\mathrm{d}(\mathrm{j} 1, \mathrm{j}), \mathrm{d}$ $(\mathrm{s}, \mathrm{j}) \quad$. Apabila $\mathrm{d}(\mathrm{s} 1, \mathrm{j}))=--$ untuk semua node $\mathrm{j}$ yang belum tertanda, maka alogaritma selesai karena tidak terdapat suatu rute dari node s1 ke node $\mathrm{j}$ tersebut. Jika tidak, tandai node $\mathrm{j}$ yang memiliki harga $\mathrm{d}(\mathrm{s} 1, \mathrm{j})$ terkecil. Misalnya node $\mathrm{j}$ yang ditandai pada langkah 1 ini adalah node j2, maka j2 menjadi S2.

\section{Langkah 2}

Ulangi langkah 1 sampai node tujuan mendapatkan tanda pada node, misalnya node $\mathrm{c}$ ditandai $\mathrm{c} 2$, maka $\mathrm{c} 2$ menjadi S2. Demikian seterusnya sampai pada titik optimal diindikasikan dengan total biaya transportasi seminim mungkin. 


\section{Hasil Analisis}

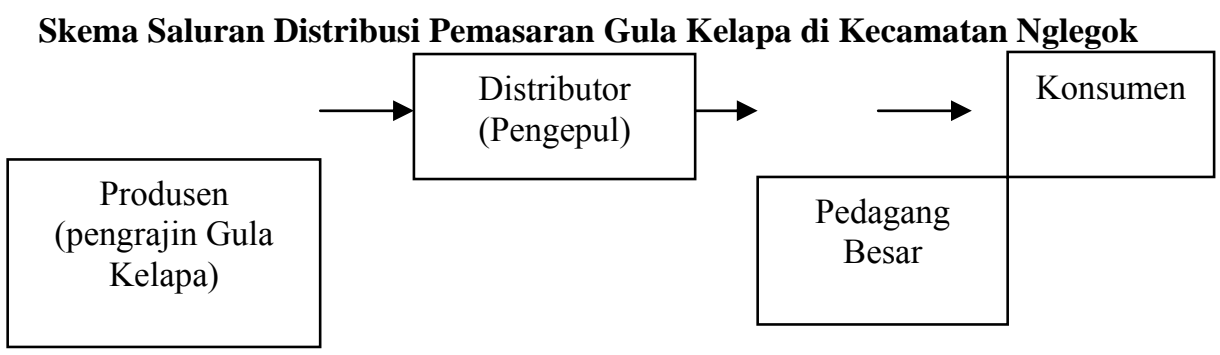

Dapat diketahui bahwa saluran distribusi yang digunakan para pengrajin gula kelapa di Kecamatan Nglegok adalah sebagai berikut : Dari produsen atau pengrajin gula kelapa seluruh hasil produksinya langsung dijual kepada distributor atau pengepul. Hubungan antara produsen dengan pengepul adalah sebagai pelanggan tetap, dimana rata-rata setiap satu pengepul mempunyai kurang lebih 5 produsen tetap yang siap menyediakan produk gula kelapa. Apabila permintaan gula kelapa lebih tinggi, biasanya pengepul tidak hanya mengandalkan penyediaan gula kelapa dari produsen tetap tetapi juga produsen dari luar wilayah ( wilayah selain produsen tetap), dengan sistem pemesanan terlebih dahulu, permintaan yang lebih tinggi ini biasa terjadi pada bulan Ramadhan, Hari Raya Idul Fitri dan terkadang juga pada waktu musim kemarau. Selanjutnya Pengepul akan menjual seluruh produknya tersebut ke konsumen (pedagang besar ) di pasar-pasar tradisional yang ada wilayah-wilayah tertentu antara lain Pare, Jombang, Tulungagung, Babat, Tuban dan lain-lain. Para pengepul dalam mendistribusian gula kelapa selama ini lebih banyak dipasarkan di pasar-pasar tradisional meskipun ada beberapa pengepul yang mendistribusikannya secara tidak langsung (ada perantara lain yang menggambil di lokasi) untuk di pasarkan di pasar-pasar modern seperti swalayan, supermarket. Dunia maya, dll. Para pengepul yang bertindak sebagai penyalur jarang sekali yang mendistribusikan langsung untuk pedagang besar lokal, mereka lebih suka memenuhi permintaan dari luar wilayah dengan pertimbangan harga jualnya lebih tinggi, serta permintaan yang selalu kontinyu. Dari hasil penelitian, pedagang-pedagang lokal Blitar lebih sering terjun langsung ke pengepul-pengepul untuk membeli Gula Kelapa yang selanjutnya akan dijual kepada konsumen akhir. 


\section{Pembahasan Data Hasil Penelitian}

Tabel A

Produksi Yang Tersedia (Supply) Dengan kebutuhan (Demand)

\begin{tabular}{|c|c|c|c|c|c|c|c|c|c|c|c|}
\hline & 1 & 2 & 3 & 4 & 5 & 6 & 7 & 8 & 9 & 10 & $S$ \\
\hline$I$ & 10000 & 30000 & & & & & & & & & 15 \\
\hline$I I$ & & & 13333 & 20588 & & & & & & & 245 \\
\hline$I I I$ & & & & 42857 & & 91667 & 64285 & & & & 40 \\
\hline$I V$ & & & & & 11428 & & & 21413 & 6438 & 15000 & 125 \\
\hline$D$ & 10 & 5 & 105 & 133 & 35 & 12 & 14 & 46.7 & 23.3 & 20 & \\
\hline
\end{tabular}

Agar produk gula kelapa bisa sesuai dengan harapan konsumen baik produsen maupun pengepul tidak sedikit untuk mengeluarkan biaya, baik dalam proses produksi yang masih dilakukan secara tradisional, promosi dan distribusi, serta pengelolaan yang masih ditangani oleh home industri, tentunya dalam permodalanpun masih sangat minim. Untuk mereduksi seluruh biaya-biaya yang dikeluarkan oleh pengusaha gula kelapa peneliti mencoba untuk memberikan solusi dengan meminimalkan biaya pemasaran salah satunya dengan upaya optimalisasi saluran distribusi.

Atas dasar kondisi riil pada tabel A maka diperlukanlah saluran distribusi yang optimal yang mampu mendukung tujuan pemasaran gula kelapa serta saluran distribusi yang sesuai dengan target pasar. Pada proses untuk memperoleh kondisi optimal diidentifikasikan dengan total biaya transportasi atau biaya transfer yang minimum. Maka sebagai tahap awal menggunakan metode Nort West Corner Methode untuk memperoleh pemecahan awal yang feasible. Selanjutnya untuk mendapatkan pemecahan yang optimal maka dikombinasikan dengan metode Modified Distribution (MODI)

Tabel B

Initial Solutian by North West Corner Method

\begin{tabular}{|c|c|c|c|c|c|c|c|c|c|c|c|c|}
\hline Tujuan & \multirow{2}{*}{ D1 } & D2 & D3 & D4 & D5 & D6 & D7 & D8 & D9 & D10 & D11 & Supply \\
\hline S1 & 10.0 & 5.0 & 0.0 & 0.0 & 0.0 & 0.0 & 0.0 & 0.0 & 0.0 & 0.0 & 0.0 & 15.0 \\
\hline S2 & 0.0 & 0.0 & 105.0 & 133.0 & 7.0 & 0.0 & 0.0 & 0.0 & 0.0 & 0.0 & 0.0 & 245.0 \\
\hline S3 & 0.0 & 0.0 & 0.0 & 0.0 & 28.0 & 12.0 & 0.0 & 0.0 & 0.0 & 0.0 & 0.0 & 40.0 \\
\hline S4 & 0.0 & 0.0 & 0.0 & 0.0 & 0.0 & 0.0 & 14.0 & 46.7 & 23.3 & 20.0 & 21.0 & 125.0 \\
\hline Demand & 10.0 & 5.0 & 105.0 & 133.0 & 35.0 & 12.0 & 14.0 & 46.7 & 23.3 & 20.0 & 21.0 & 425.0 \\
\hline
\end{tabular}

Initial Solution : 6938165.5 
Hasil analisis pada table B dapat diketahui bahwa pengalokasian pendistribusian mengalami perubahan. Dari hasil analisis pengepul I tidak menunjukkan perubahan pengalokasian karena wilayah Wlingi dan Kesamben sudah menunjukkan keoptimalan saluran distribusi. Ada beberapa rekomendasi yang bisa dilakukan oleh para pengepul gula kelapa yaitu untuk pengepul II akan lebih optimal jika mendistribusikan gula kelapa sebanyak $105 \mathrm{kw} /$ minggu ke Pare, $133 \mathrm{kw} /$ minggu Jombang dan ke Tulungagung sebanyak $7 \mathrm{kw} /$ minggu. Untuk pengepul III pendistribusian yang optimal sebanyak $28 \mathrm{kw} /$ minggu ke Tulungagung dan $12 \mathrm{kw} /$ minggu ke Tuban. Sedangkan pengepul IV alokasi lebih optimal jika pendistribusian tidak dilakukan ke wilayah Tulungagung akan tetapi di distribusikan sebanyak $14 \mathrm{kw} /$ minggu ke Babat. Hal ini adalah atas dasar metode analisis North West Corner Method (NWCR) dengan indkator optimal adalah solusi biaya pengiriman sebesar Rp.6.938.165,5. Setelah dianalisis dengan NWCR biaya pengiriman gula kelapa menjadi lebih kecil dibandingkan dengan kondisi aktual sebesar Rp. 8.550.000

Tabel C

Produksi Yang Tersedia (Supply) Dengan Kebutuhan (Demand) Seimbang Alokasi ke Wlingi

\begin{tabular}{|c|c|c|c|c|c|c|c|c|c|c|c|}
\hline & 1 & 2 & 3 & 4 & 5 & 6 & 7 & 8 & 9 & 10 & $S$ \\
\hline$I$ & 10000 & 30000 & & & & & & & & & 15 \\
\hline$I I$ & 4762 & & 13333 & 20588 & & & & & & & 245 \\
\hline$I I I$ & & & & 42857 & & 91667 & 64285 & & & & 40 \\
\hline$I V$ & & & & & 11428 & & & 21413 & 6438 & 15000 & 125 \\
\hline$D$ & 31 & 5 & 105 & 133 & 35 & 12 & 14 & 46.7 & 23.3 & 20 & \\
\hline
\end{tabular}

Tabel D

Initial Solutian By Northwest Corner Method

\begin{tabular}{|c|c|c|c|c|c|c|c|c|c|c|c|}
\hline $\begin{array}{c}\text { Tujuan } \\
\text { Asal }\end{array}$ & D1 & D2 & D3 & D4 & D5 & D6 & D7 & D8 & D9 & D10 & Supply \\
\hline S1 & 15.0 & 0.0 & 0.0 & 0.0 & 0.0 & 0.0 & 0.0 & 0.0 & 0.0 & 0.0 & 15.0 \\
\hline S2 & 16.0 & 5.0 & 105.0 & 119.0 & 0.0 & 0.0 & 0.0 & 0.0 & 0.0 & 0.0 & 245.0 \\
\hline S3 & 0.0 & 0.0 & 0.0 & 14.0 & 26.0 & 0.0 & 0.0 & 0.0 & 0.0 & 0.0 & 40.0 \\
\hline S4 & 0.0 & 0.0 & 0.0 & 0.0 & 9.0 & 12.0 & 14.0 & 46.7 & 23.3 & 20.0 & 125.0 \\
\hline Demand & 31.0 & 5.0 & 105.0 & 133.0 & 35.0 & 12.0 & 14.0 & 46.7 & 23.3 & 20.0 & 425.0 \\
\hline
\end{tabular}

Initial Solution : 6228971.5 
Tabel $\mathrm{C}$ adalah data simulasi alokasi sebanyak $21 \mathrm{kw} /$ minggu ke Wlingi, untuk tabel 4.15 adalah hasil analisis. Pada tabel D kondisi optimal dengan biaya minimumnya Rp. 6.228.971,5, nampaknya solusi biaya minimum alokasi ke Wlingi ini menunjukkan biaya pengiriman yang paling rendah dibandingkan dengan kondisi riil dan simulasi alokasi yang lainnya. Variasi distribusi optimalnya cukup beragam, yaitu untuk pengepul I cukup mendistribusikan gula kelapa ke Wlingi sebanyak $15 \mathrm{kw} /$ minggu. Pengepul II sebanyak $16 \mathrm{kw} /$ minggu ke Wlingi, 5 $\mathrm{kw} /$ minggu ke Kesamben, $105 \mathrm{kw} /$ minggu ke Pare, $119 \mathrm{kw} /$ minggu ke Jombang. Untuk pengepul III sebanyak $14 \mathrm{kw} /$ minggu ke Jombang, dan $26 \mathrm{kw} /$ minggu ke Tulungagung. Sedangkan untuk pengepul IV sebanyak $9 \mathrm{kw} /$ minggu ke Tulungagung, $12 \mathrm{kw} /$ minggu ke Tuban, $14 \mathrm{kw} /$ minggu ke Babat, 46,7 ke Surabaya, $23,3 \mathrm{ke}$ Talun dan $20 \mathrm{kw} /$ minggu ke Batu.

Tabel E

Optimal Solution By MODI (Kondisi riil)

\begin{tabular}{|l|l|l|l|l|l|l|l|l|l|l|l|l|}
\hline $\begin{array}{c}\text { Tujuan } \\
\text { Asal }\end{array}$ & D1 & D2 & D3 & D4 & D5 & D6 & D7 & D8 & D9 & D10 & D11 & Supply \\
\hline S1 & 0.0 & 0.0 & 7.0 & 8.0 & 0.0 & 0.0 & 0.0 & 0.0 & 0.0 & 0.0 & 0.0 & 15.0 \\
\hline S2 & 10.0 & 5.0 & 58.0 & 0.0 & 35.0 & 12.0 & 14.0 & 46.7 & 23.3 & 20.0 & 21.0 & 245.0 \\
\hline S3 & 0.0 & 0.0 & 40.0 & 0.0 & 0.0 & 0.0 & 0.0 & 0.0 & 0.0 & 0.0 & 0.0 & 40.0 \\
\hline S4 & 0.0 & 0.0 & 0.0 & 125.0 & 0.0 & 0.0 & 0.0 & 0.0 & 0.0 & 0.0 & 0.0 & 125.0 \\
\hline Demand & 10.0 & 5.0 & 105.0 & 133.0 & 35.0 & 12.0 & 14.0 & 46.7 & 23.3 & 20.0 & 21.0 & 425.0 \\
\hline
\end{tabular}

Optimal Solutian : 773314.0

Hasil analisis menggunakan MODI dapat diketahui bahwa total biaya pemasaran dalam pendistribusian Gula Kelapa per minggu mengalami penurunan, diketahui bahwa biaya pemasaran semula sebesar Rp. 8.550.000,-. Namun setelah dianalisis menggunkan MODI mengalami penurunan menjadi Rp. 773.314,-. Hal ini dikarenakan pada analisis MODI tujuan pendistribusian ditujukan pada daerah yang efektif dan efisien, sehingga biaya pemasaran dapat diminimalisasikan.

Berdasarkan tabel E juga dapat diterangkan bahwa pengalokasian pendistribusian gula kelapa telah berubah. Sesuai dengan hasil analisis, pendistribusian yang optimal dan yang sesuai dengan target pasar gula kelapa adalah dengan biaya Rp. 773.314,-. Pengepul I akan mendapatkan hasil pendistribusian yang optimal apabila gula kelapa di distribusikan ke wilayah Pare sebanyak $7 \mathrm{kw} /$ minggu dan $8 \mathrm{kw} /$ minggu ke Jombang. Pengepul II mendistribusikan sebanyak 10kw/minggu ke Wlingi, 5kw/minggu ke Kesamben, $58 \mathrm{kw} /$ minggu ke Tulungagung, $12 \mathrm{kw} / \mathrm{minggu}$ ke Tuban, $14 \mathrm{kw} /$ minggu ke Babat, $46,7 \mathrm{kw} / \mathrm{minggu}$ ke Surabaya, 23,3kw/minggu ke Talun, dan $20 \mathrm{kw} /$ minggu ke Batu. Untuk pengepul III pendistribusian yang optimal sebesar $40 \mathrm{kw} /$ minggu ke Pare. Sedangkan untuk pengepul IV pendistribusian lebih optimal apabila gula kelapa di distribusikan ke 
Jombang sebanyak $125 \mathrm{kw} /$ minggu. Hal ini adalah rekomendasi pendistribusian atas dasar model analisis MODI.

Tabel F. Optimal Solution By MODI

(Simulasi Alokasi ke Tulungagung)

\begin{tabular}{|c|c|c|c|c|c|c|c|c|c|c|c|}
\hline $\begin{array}{c}\text { Tujuan } \\
\text { Asal }\end{array}$ & D1 & D2 & D3 & D4 & D5 & D6 & D7 & D8 & D9 & D10 & Supply \\
\hline S1 & 0.0 & 0.0 & 7.0 & 8.0 & 0.0 & 0.0 & 0.0 & 0.0 & 0.0 & 0.0 & 15.0 \\
\hline S2 & 10.0 & 5.0 & 58.0 & 0.0 & 56.0 & 12.0 & 14.0 & 46.7 & 23.3 & 20.0 & 245.0 \\
\hline S3 & 0.0 & 0.0 & 40.0 & 0.0 & 0.0 & 0.0 & 0.0 & 0.0 & 0.0 & 0.0 & 40.0 \\
\hline S4 & 0.0 & 0.0 & 0.0 & 125.0 & 0.0 & 0.0 & 0.0 & 0.0 & 0.0 & 0.0 & 125.0 \\
\hline Demand & 10.0 & 5.0 & 105.0 & 133.0 & 56.0 & 12.0 & 14.0 & 46.7 & 23.3 & 20.0 & 425.0 \\
\hline
\end{tabular}

Optimal Solutian : 773314.0

Tabel F menunjukkan hasil optimalisasi distribusi jika supply dan demand seimbang, dari hasil analisis kita dapat melihat bahwa optimal solution sebesar Rp. 773.314,-. Hasil simulasi ini tidak menunjukkan perbedaan terhadap hasil analisis pada kondisi riil, adapun untuk pengalokasian distribusinya juga menunjukkan kesamaan pada hasil analisis kondisi riil, perbedaan hanya terjadi pada jumlah alokasi distribusi dari pengepul II ke konsumen Tulungagung sebesar 35 $\mathrm{kw} /$ minggu. Untuk pengalokasian distribusi baik pengepul maupun konsumen lainnya menunjukkan kesamaan dengan alokasi distribusi pada kondisi riil.

Berdasarkan tabel Frekomendasi distribusi yang optimal adalah pengepul I alokasi distribusi ke wilayah Pare sebanyak $7 \mathrm{kw} /$ minggu dan $8 \mathrm{kw} /$ minggu ke Jombang. Pengepul II mendistribusikan sebanyak $10 \mathrm{kw} /$ minggu ke Wlingi, 5 $\mathrm{kw} /$ minggu ke Kesamben, $58 \mathrm{kw} /$ minggu ke Tulungagung, $12 \mathrm{kw} /$ minggu ke Tuban, $14 \mathrm{kw} /$ minggu ke Babat, 46,7 kw/minggu ke Surabaya, 23,3 kw/minggu ke Talun, dan $20 \mathrm{kw} /$ minggu ke Batu. Untuk pengepul III pendistribusian yang optimal sebesar $40 \mathrm{kw} /$ minggu ke Pare. Sedankan untuk pengepul IV rekomendasi pendistribusian yang optimal sebanyak $125 \mathrm{kw} /$ minggu ke Jombang. 
Gambar

Jaringan Pemasaran Rute Transportasi Gula Kelapa

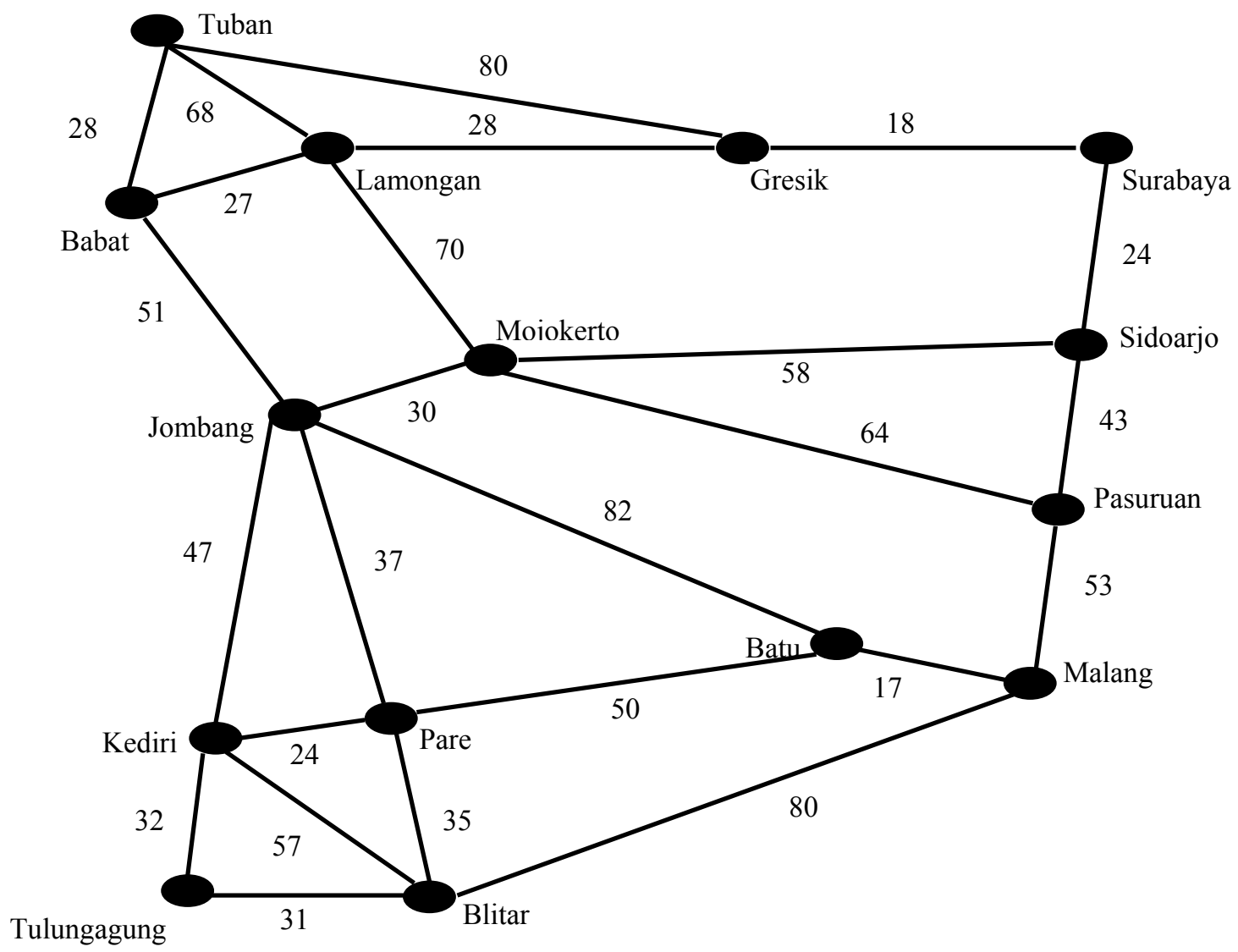




\section{KESIMPULAN}

Saluran distribusi yang digunakan oleh para pengepul gula kelapa di Kecamatan Nglegok Kabupaten Blitar kurang optimal. Hal ini di dukung dari data sebagai berikut:

1. Saluran distribusi yang optimal yang mampu untuk mendukung tujuan pemasaran gula kelapa dengan analisis NWCR adalah dengan solusi biaya pengiriman sebesar Rp. 6.938.166. Sedangkan dengan analisis MODI solusi biaya pengiriman sebesar Rp. 773.314,-. Kondisi aktual menunjukkan biaya pemasaran semula sebesar Rp. 8.550.000,-. Namun setelah dianalisis menggunkan NWCR maupun MODI mengalami penurunan. Dari hasil analisis dengan menggunakan NWCM total biaya pengiriman dalam pendistribusian gula kelapa per minggu mengalami penurunan sebesar Rp 1.611.834, sedangkan dengan menggunakan MODI penurunan biaya pengiriman sebesar Rp. 7.776.686,-. Terjadinya penurunan distribusi ini memberikan indikasi yang optimal.

2. a) Saluran distribusi yang sesuai dengan target pasar dalam pemasaran gula kelapa dengan analisis NWCR ditunjukkan dengan alokasi distribusi gual kelapa sebanyak $105 \mathrm{kw} /$ minggu ke Pare, 133 $\mathrm{kw} /$ minggu ke Jombang dan $7 \mathrm{kw} /$ minggu ke Tulungagung untuk pengepul II. Pengepul III saluran distribusi yang sesuai dengan target pasar adalah dialokasikan ke Tulungagung sebanyak $28 \mathrm{kw} /$ minggu dan ke Tuban sebanyak $12 \mathrm{kw} /$ minggu. Untuk pengepul IV dialokasikan ke Babat sebanyak $14 \mathrm{kw} /$ minggu, Surabaya 46,7 $\mathrm{kw} /$ minggu, Talun $23.3 \mathrm{kw} /$ minggu dan Batu $21 \mathrm{kw} /$ minggu. Dan untuk pengepul I dari hasil analisis saluran distribusinya sudah sesuai dengan target pasar. Hasil analisis dengan MODI saluran distribusi yang sesuai dengan target pasar ditunjukkan dengan pengalokasian pendistribusian gula kelapa dengan rekomendasi Pengepul I mendistribusikan ke wilayah Pare sebanyak $7 \mathrm{kw} /$ minggu dan $8 \mathrm{kw} /$ minggu ke Jombang. Pengepul II mendistribusikan sebanyak $10 \mathrm{kw} /$ minggu ke Wlingi, 5kw/minggu ke Kesamben, 58kw/minggu ke Tulungagung, $12 \mathrm{kw} /$ minggu ke Tuban, $14 \mathrm{kw} /$ minggu ke Babat, 46,7 kw/minggu ke Surabaya, 23,3kw/minggu ke Talun, dan $20 \mathrm{kw} /$ minggu ke Batu. Untuk pengepul III sebesar 40kw/minggu ke Pare. Sedangkan untuk pengepul IV alokasi pendistribusikan ke Jombang sebanyak $125 \mathrm{kw} /$ minggu.

b) Dari beberapa simulasi yang telah diteliti dengan analisis NWCR, Simulasi supply dan demand seimbang dengan jalan mengalokasikannya sebanyak $21 \mathrm{kw} /$ minggu ke Wlingi ini adalah bentuk simulasi yang dinilai lebih optimal dibandingkan dengan 
simulasi-simulasi yang lainnya, dengan solusi biaya pengiriman sebesar Rp. 6.228.972,-. Sedangkan untuk analisis MODI simulasi yang menunjukkan tingkat keoptimalannya adalah bentuk simulasi supplay dan demand seimbang dengan alokasi $21 \mathrm{kw} /$ minggu $\mathrm{ke}$ Tulungagung dengan optimal solution sebesar Rp. 773.314,-

3.. Jaringan pemasaran yang mendukung pemasaran gula gelapa adalah suatu jaringan yang efektif, efisien, dan optimal, ditunjukkan dengan variasi rute pengiriman yang paling pendek untuk sampai pada saluran distribusi yang dituju. Dari hasil analisis untuk titik awal Blitar tujuan pemasaran Pare ada 3 variasi, titik awal Blitar tujuan Jombang ada 6 variasi, titik awal Blitar tujuan pemasaran Batu terdapat 6 variasi, titik awal Blitar dengan tujuan pemasaran Surabaya terdapat 7 variasi, titik awal Blitar tujuan pemasaran Babat terdapat 8 variasi, dan titik awal Blitar tujuan pemasaran Tuban terdapat 9 variasi. Dari beberapa variasi rute pengiriman, Pare menjadi rute alternatif untuk pengiriman gula kelapa. 


\section{DAFTAR PUSTAKA}

Agustin, Dwi Hayu dan Yus Endra Rahmadi, 2004. Riset Operasional(Konsepkonsep Dasa), Penerbit PT Asdi Mahasatya, Jakarta.

Antemas,Efrial , 2006. Analisis Jaringan Proses Kerja untuk Pengendalian Waktu dan Sumberdaya Produksi (Studi Kasus: Produksi Map Plug di CV. TU Bekasi) www.elibrary.mb.ipb.ac.id, 21 Januari 2009.

Dimyati, Tjutju Tarliah dan Ahmad Dimyati, 1992. Operations Research (Modelmodel Pengambilan Keputusan), Penerbit Sinar Baru Algensindo, Jakarta.

Gunara, Torik dan Utus Hardiono Sudibyo, 1997. Marketing Muhammad, Penerbit Madania Prima, Bandung.

Heizer, jay dan Barry Render, 2004. operating Management. Edisi ketujuh buku 2, Penerbit salemba empat, Jakarta.

http://tesis-skripsi.blogspot.com/2008/01/analisis-pendapatan-dan efisiensigula.html diakses tanggal 16 maret 2009.

Kotler, Philip, 2001. Prinsip-Prinsip Pemsara. Jilid 2, Penerbit Erlangga, Jakarta. Jakarta.

Kotler, Philip dan Gary Armstrong, 1998. Dasar-Dasar Pemasaran. Jilid 2, Penerbit Prenhallindo, Jakarta.

Majalah Marketing, 2008. Inspiring The Leadership. No 05/VIII/MEI/2008, Jakarta.

Masyhuri, dkk, 2008. Optimalisasi Distribusi Singkong yang Berimbang (Balance) Guna Mendukung Ketahanan Pangan di Jawa Timur. Laporan Penelitian Hibah Bersaing tahun I, DIKTI 2008.

Masyhuri dan Zainuddin, 2008. Metodologi Penelitian. Pendekatan Praktek dan Aplikatif, PT. Refika Aditama, Bandung.

Mulyono, Sri, 2004. Riset Operasi. Edisi revisi (2007), Penerbit Lembaga Penerbit Fakultas Ekonomi UI, Jakarta.

Nurdiana, Ilfi, 2008. Hadist-Hadist Ekonomi, Penerbit UIN-Malang Press, Malang.

Qardhawi, Yusuf, 2001. Peran Nilai dan Moral Dalam Perekonomian Islam, Penerbit Robbani Press, Jakarta.

Rayon, Frans M, 2005. Sun Tzu Creating Distribution Strategy, Penerbit PT Gramedia Pustaka Utama, Jakarta.

Rohman, Fatchur, 2008. Bahan Ajar Operations Research, Penerbit JM-FE-UB, Malang.

Setyowati, Endang, dkk, 2003. Pengantar Ekonomi Mikro, Penerbit Sekolah Tinggi Ilmu Ekonomi (STIE), Yogyakarta.

Sugiono, 2001. Metode Penelitian Bisnis, Penerbit PT. Alfabeta, Bandung. 
211 
215 
216 
221 
222 
223 
225 
226 
229 
272 
291 
294 
295 
296 
411 
421 
425 
